\title{
A DESCRIPTIVE STUDY TO ASSESS THE PREVALENCE OF EXCESSIVE MOBILE PHONE USAGE AMONG NURSING STUDENTS STUDYING IN SELECTED COLLEGE OF AMRITSAR (PUNJAB).
}

Dr. Arundeep Kaur ${ }^{*}$ | Dr. Mandeep Kaur**

*Associate Professor, CKD International Nursing College, Amritsar, Punjab, India.

*Associate Professor, CKD International Nursing College, Amritsar, Punjab, India. DOI: http://doi.org/10.47211/tg.2020.v07iws01.009

Received $12^{\text {th }}$ June 2020, Accepted $20^{\text {th }}$ June 2020, Available online $30^{\text {th }}$ June 2020.

\begin{abstract}
:
Worldwide, technology especially the mobile phones have considerably new of this century. The current trend of the society is to adopt every change is the field of communication technology. The mobile phones are been of this century. They are considered as an important communication tool and become the integral part of the society, it is not only a communication device but it is also necessary social accessory. People are increasingly using mobile phone rather than the fixed telephones. The mobile phone is a lifeline for many. To recapitulate, as we know excessive mobile phone usage are having many deleterious effects on individual's life. So this research study aims to provide them knowledge about many health problems related to excessive mobile phone usage such as lack of concentration, stress, low grades, lack of vision, cyber bullying. Hence, its prolong use should be considered and it is not to be cherish. For the present study, non-experimental approach was considered appropriate as it aimed to assess the prevalence of excessive mobile usage among nursing students. Descriptive research design was utilized to achieve the objectives of the study. The study was conducted in Chief Khalsa Diwan International Nursing College, Amritsar. The population of present study was nursing students. 200 nursing students in age group 18-25 years studying in Chief Khalsa Diwan Nursing College, Amritsar, were selected by purposive sampling technique. A self-structured checklist was used to assess the prevalence of excessive mobile phone usage among nursing students. 164(82\%) were in 18-21 years of age and $36(18 \%)$ were in 22- 25 years of age. 155(77.5\%) of nursing students were female and $45(22.5 \%)$ were male. 101(50.5\%) of nursing students were from rural area and 99(49.5\%) were from urban area. 122(61\%) had income of less than Rs.1,00,000/- annually and 62(31\%) had income of Rs. 2,00,000-3,00,000/- annually. 183(91.5\%) of nursing students use smart and 17(8.5\%) of nursing students use Non-smart phone.
\end{abstract}

KEY WORDS: Mobile phone, excess usage mobile, nursing students. 


\section{INTRODUCTION}

The mobile phones are been of this century. They are considered as an important communication tool and become the integral part of the society, it is not only a communication device but it is also necessary social accessory. People are increasingly using mobile phone rather than the fixed telephones. The mobile phone is a lifeline for many. Balakrishnan V., 2012 reported that smart phone use has adversely affected learning in the classroom has endangered during safety and has negatively affected work performance

\section{NEED OF THE STUDY}

B. Prati, Chakrabotary P $\mathbf{2 0 1 7}$ said that it is true that smart phone is quite essential for many different field of profession, diversion of mobile phone like listening songs, communication, social networking, chatting is now pass beyond or exceed its basic needed in daily life. Although smart phones and internet are used as communication tool, excessive use of these technological tools causes individual to become addicted. Recently, the rate of spreading smart phones is gradually increasing among people. The more and more people individual started to use smart phones because of introduction of cheap phone in market which is $50 \%$ lower in cost than actual price of smart phone. However, noticeable change is that among children the rate of addiction increased before school from 3.6 percent to $4.3 \%$.

\section{AIM OF THE STUDY}

To assess the prevalence of excessive mobile phone usage among nursing students.

\section{METHODOLOGY}

For the present study, non-experimental approach and descriptive research design was considered appropriate as it aimed to assess the prevalence of excessive mobile usage among nursing students. The study was conducted in Chief Khalsa Diwan International Nursing College, Amritsar. The population of present study was nursing students. The sample and sample size was 200 nursing students in age group 18-25 years studying in Chief Khalsa Diwan Nursing College, Amritsar. Purposive sampling technique was used to select the sample. The tool consisted of 2 sections: Section A: selected socio-demographic variables such as age, gender, residence, income of parents, family type, type of phone. Section B: Self structured checklist Reliability of tool was determined by split half method.

\section{RESULTS}

Table 1

Frequency and percentage distribution of demographic variables

\begin{tabular}{|c|c|c|c|}
\hline \multirow{2}{*}{ S. NO } & \multirow[b]{2}{*}{ Demographic Variable } & \multicolumn{2}{|c|}{$\mathbf{N}=\mathbf{2 0 0}$} \\
\hline & & $f$ & $\%$ \\
\hline \multirow[t]{3}{*}{1.} & Age & & \\
\hline & a. $18-21$ years & 164 & 82 \\
\hline & b. $22-25$ years & 36 & 18 \\
\hline \multirow[t]{3}{*}{2} & Gender & & \\
\hline & a. Male & 45 & 22.5 \\
\hline & b. Female & 155 & 77.5 \\
\hline \multirow[t]{3}{*}{3} & Residence & & \\
\hline & a. Rural & 101 & 50.5 \\
\hline & b. Urban & 99 & 49.5 \\
\hline \multirow[t]{4}{*}{4} & Income of parents & & \\
\hline & a. Less than $1,00,000$ annually & 122 & 61 \\
\hline & b. $2,00,000-3,00,000$ annually & 62 & 31 \\
\hline & c. $4,00,000-5,00,000$ annually & 16 & 8 \\
\hline \multirow[t]{4}{*}{5} & Family type & & \\
\hline & a. Single parent & 38 & 19 \\
\hline & b. Nuclear & 124 & 67 \\
\hline & c. Compound & 28 & 14 \\
\hline \multirow[t]{3}{*}{6} & Type of phone & & \\
\hline & a. Smart phone & 183 & 91.5 \\
\hline & b. Non smart phone & 17 & 8.5 \\
\hline
\end{tabular}




\section{ARTICLES}

Table 2

Prevalence of excessive mobile phone usage among nursing students

\begin{tabular}{llllll} 
& & \multicolumn{3}{c}{$\mathbf{N}=\mathbf{2 0 0}$} \\
\hline S.No & Prevalence & $(\mathrm{n})$ & $\%$ & Mean & SD \\
\hline 1 & Mild prevalence & 48 & 24 & 4.5 & 1.458 \\
2 & Moderate prevalence & 119 & 59.5 & 9.96 & 1.615 \\
3 & High prevalence & 33 & 16.5 & 14.18 & 1.044 \\
& & & 9.35 & 3.464 \\
\hline
\end{tabular}

$164(82 \%)$ were in $18-21$ years of age and $36(18 \%)$ were in $22-25$ years of age. $155(77.5 \%)$ of nursing students were female and $45(22.5 \%)$ of nursing students were male. $101(50.5 \%)$ of nursing students are from rural area and 99(49.5\%) of nursing students are from urban area. 122(61\%) had income of Less than Rs.1,00,000 annually and $62(31 \%)$ had income of Rs. 2,00,000-3,00,000 annually. 38(19\%) belongs to single parent family and $124(67 \%)$ belongs to nuclear family. 183(91.5\%) of nursing students use smart and $17(8.5 \%)$ of nursing students use Non-smart phone. $48(24 \%)$ of nursing students had mild prevalence, $119(59.5 \%)$ of nursing students had moderate prevalence and 33(16.5\%) of nursing students had high prevalence of excessive mobile phone usage. There is no significant association found between demographic variables such as age, gender, residence, income of parents, family type and use of smart phone with prevalence of excessive use of mobile phone among nursing students.

\section{CONCLUSION}

The findings of the study concluded that mobile phone usage is common among nursing students. As an advance in technology, mobile phone addiction is an important problem among students. The results of the present study showed that $48(24 \%)$ of nursing students had mild, 119 (59.5\%) of nursing students had moderate and $33(16.5 \%)$ of nursing students had high prevalence of excessive mobile phone usage. Mobile phone usage has some harmful effects on health. Administration action is required to reduce the usage of mobile phone among students in order to promote the health and to improve the performance in academic activities of students.

\section{REFERENCES}

1. Balakrishnana V, Ray Ra. Exploring the relationship between urbanized Malaysian Youth \& their mobile phones a quantitative approach phones a quantitative approach. Telemost inform 2012: 29(3) 263-272.

2. Pratibhakhosla, Piyali Chakrabotang Int J. Pharm. Sci. Rev. Res., 26(1), September-October 2017, Article No. 17, pp. 91-94. 